\section{Corporate Social Responsibility and Sustainable Development - A Study of S\&P BSE 100 Companies}

\author{
Amit Kumar Arora \\ KIET Group of Institutions, Ghaziabad, India \\ Ankit Panchal \\ KIET Group of Institutions, Ghaziabad, India \\ Priya Rathi \\ Shiv Nadar University, Greater Noida, India, and \\ Vijay Prakash Gupta \\ Institute of Technology \& Science (I.T.S), Mohan Nagar, Ghaziabad, India
}

\section{Abstract}

Purpose- This study is an attempt to study the overview of CSR provisions' applicability and trends of S\&P BSE 100 Companies. To determine whether there is any significant difference in the actual expenditure on CSR and the expenditure to be done as per the CSR provision of Company Act 2013.

Design/methodology/approach - The study is descriptive and cross-sectional study. Descriptive statistics and t-test have been used to analyze the data.

Findings - The study found no significant difference in the actual expenditure on CSR and the expenditure to be done as per the CSR provision of the Company Act 2013.The actual amount spent on CSR is increasing and the unspent amount on CSR is decreasing throughout the study. Numbers of companies are increasing which are spending more amount as per the provision. Most of the companies are spending on health care, education, rural development, gender equality, and slum area development, etc., mostly the elements which are used as a tool for sustainable development.

Research Limitations/implications - The study is based on the secondary data and considered the S\&P BSE 100 Companies only.

Practical implications - The study shows that the implications of CSR provision will be fruitful for stakeholders, society and environment as well as for the sustainable development of the Indian economy.

Originality - The study has mainly focused on applicability of CSR provision and trends of S\&P BSE 100 Companies on the basis of cross-sectional study and tested a descriptive item which shows actual expenditure on CSR and the expenditure to be done as per the CSR provision of the Company Act 2013 a tool for sustainable development.

Keywords - CSR, Sustainable Development, CSR provision of Company Act 2013.

Paper type- Research paper.

\section{Introduction}

"Earn your crores but understand that your wealth is not yours; it belongs to society. Take what you require for your legitimate needs and use the remainder for society". -Mahatma Gandhi. As per our moral values concerned, whatever we have taken from nature, society, and the environment, we have to give something to return to make a balance. Corporate Social Responsibility (CSR) means to give a portion of earning of the Company (which is done by using the resources from nature and society) for the societal growth and development; it may be through healthcare, education, poverty, safety or any other factor for improvement of environment $\&$ any other social issues. The World Business Council for Sustainable Development gave the definition of CSR i.e. "Corporate Social Responsibility is the continuing commitment by business to behave ethically and contribute to economic development while improving the quality of life of the workforce and their families as well as
Corporate Social

Responsibility and

Sustainable Development

Received: 29.05 .2020 Revised: 11.07.2020 21.08 .2020

Accepted: 07.09.2020 


\begin{tabular}{ll}
\hline \hline GBR \\
Vol. 16 \\
109
\end{tabular}

local community and society at large." Section 135 of Companies Act 2013 put the obligations on companies to spend on CSR. Tata Group was the one who came with the existence of CSR.CSR has two heads, one is that it contributes to social responsibility and the second head is that it shows ethical behavior in the society where the business runs.

Our society is facing challenges like Poverty, Demographic, Economically, Growth, Urbanization, these put the pressure on the Environment and Scarcity of Resources. Sustainable Development means the development and improvement of quality life of society at present without compromising future resources; it meant the development of society in such a way to make efficient use of current resources without future scarcity. The improvement in Healthcare, Education, Resources, Quality of life, etc. is required so that it does not cause any damage to society or future resources and needs.

All the contribution area of CSR defined by Schedule VII of Companies Act 2013, (Enhancement of learning \& education, reduce the number of the population who are living below the poverty line, Reducing the death of infant child, and also take care of the health of lactating mothers, Gender equality, Ensuring environmental sustainability, Social business projects, Health Care, Rural development projects, Slum area Development, etc.) are mostly the elements which are used as a tool for sustainable development. So, it can be said that CSR is the activity used for the Sustainable Development of the society.CSR in India is now accepted as a motto to gain sustainable development. An organization can go through sustainable development, if and only if that organization has CSR as its integral part of the Business.

CSR Provision as per Companies Act-2013

The following Figure-1 is showing the applicability of CSR Provision as per Companies Act2013, which states that any company having annual turnover of Rs. 1000 crore or more, having a net worth of Rs. 500 crore or more or having a net profit of Rs. 5 crore or more have to spent $2 \%$ of the average net profit on CSR.

Figure 1.

Rule for the applicability of CSR Provision as per Companies Act -2013

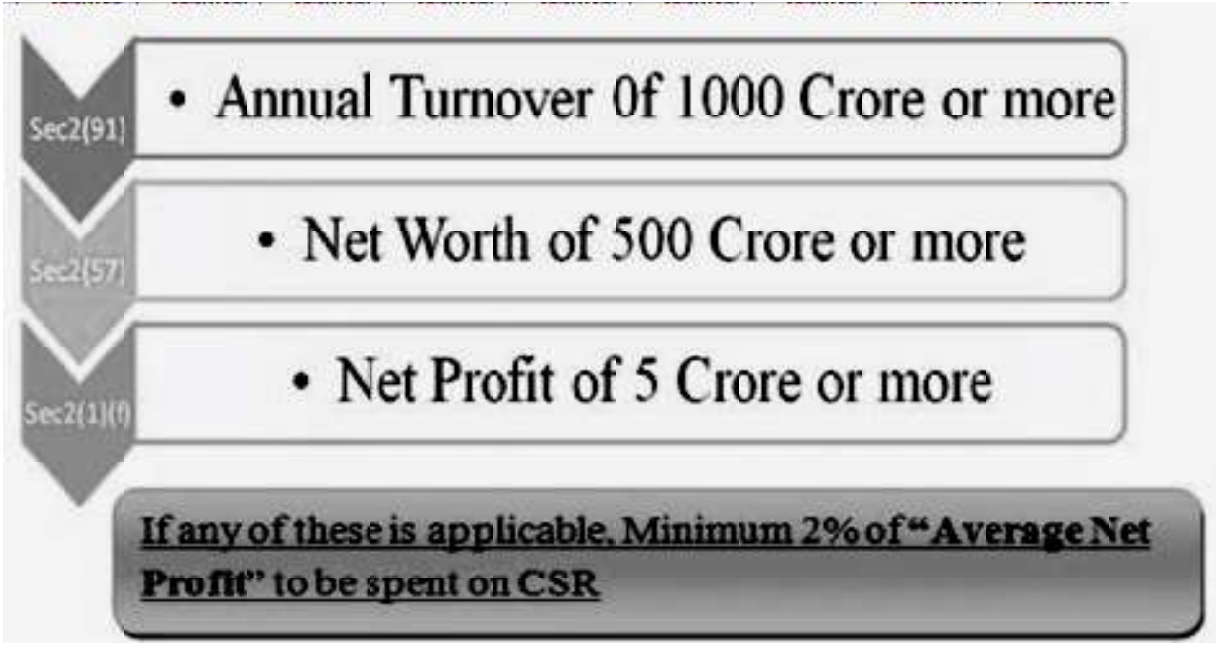

1.1 The main objectives of the Study

The main objectives of the researcher through this study are to know the answer to the following research questions:

1. To study the overview of CSR provisions applicability and trend of S\&P BSE 100 Companies.

2. To determine the expenditure on CSR to be made as per the provision and actual expenditure is done by the S\&P BSE 100 Companies.

3. To determine whether there is any significant difference in the actual expenditure on CSR and the expenditure to be done as per the CSR provision of Company Act 2013.

4. To study the Compound Annual Growth Rate of Actual amount spend on CSR activity, unutilized amount of CSR and amount to be spent on CSR activity as per the provision of companies act, 2013. 


\begin{tabular}{lr}
\hline \hline 2. Literature Review & $\begin{array}{r}\text { Corporate Social } \\
\text { Responsibility and } \\
\text { Under this literature review section our focus is on those research papers which have done } \\
\text { the study of CSR provisions' applicability and CSR trends of various companies on general }\end{array}$ \\
$\begin{array}{l}\text { Sustainable Development } \\
\text { or specific business models and researcher has tried to investigate the literature with various }\end{array}$ & $\mathbf{1 1 0}$ \\
approaches and aspect i.e. Theoretical Approach, Quantitative Approach, Business Ethics &
\end{tabular}
approaches and aspect i.e. Theoretical Approach, Quantitative Approach, Business Ethics Approach, Innovative Approach for the better understanding of the literature and to analyze the gap.

\subsection{Concept of CSR \& Sustainable Development (Theoretical Approach)}

In any business organization CSR is considered as one of the most important instances for the sustainable development of those organizations because CSR initiative will be highly profitable for the companies those who are more engaged in CSR activities.

We begin our review of literature with two research papers on CSR initiative and sustainable development; the credit for the first papers goes to (Kumar 2019) \& who has tried to find out the relationship between the Sustainable Development (SD) and CSR. The researcher analyzes that in the strategies of all the operation function, CSR should be an integral part of it. CSR should be the focus on the areas that are specified and help in improving the current scenario without harming the future. CSR should be a platform for the proper Sustainable Development of society. She determines that CSR is a business tool which is all about the company's core value, it includes Human Rights, Stake Holder Right, Employee Right, Environment Protection, Community involvement, etc. it is found from the study that CSR and SD are linked with each other with the objective of the development of society and in second paper credit goes to (Dodh, Singh, and Ravita 2013) who has highlighted the importance of CSR in protecting the environment and improving quality of life with more participation of Business Entrepreneur. So, the role of CSR towards attaining the goal of Sustainable Development as well as the contribution of CSR in attaining the goal of Sustainable Development may encourage more participation in CSR. In India, it is found that the best CSR ranking is attained by the Public Sector. India is sensitive and active towards the improvement of common masses harmonious and welfare-oriented developmental approach which focuses on CSR are governs by sufficient laws. The goal of achieving CSR has limited success in India. For ensuring the participation of National and Multinational firms to CSR, it has become a difficult part of the government to encourage them about provisions of implementing CSR.

The trend of CSR should be changed to the propagation of renewable sources of energy. Further, by analyzing the secondary data it was found in the study that there are the relationship between Sustainable Development and Corporate Social Development based on Sustainable Development process.

The relation between CSR and Sustainable Development in respect of the theoretical approach is further explored by (Behringer and Szegedi 2016) and he found that the Companies have a more practical approach to CSR by Sustainable Development in respect of the theoretical approach. It is also found that in recent years the interaction between the CSR and Sustainable Development strengthens. Sustainable Development is a managerial approach to CSR while Corporate Sustainability is the Company (Corporate) version of SD as well as (Kumar 2019) has supported the study of studied (Behringer and Szegedi 2016) and he also analyzed the secondary data from journals, newspaper, reports, etc. to explore the concept of CSR and to analysis the various models of Corporate Social Responsibility. He analysis the various model of CSR; Ethical Model, Statistics' Model, Liberal Model, and Stakeholder Model. From 1990 till now the Companies are working on the Stakeholder Model of CSR in India. He also found some areas which are the challenges for CSR i.e., growing environmental pressure, Populations demographics, Corruption, CSR as a marketing tool, Role of Technology, etc. Companies in India are more focusing on HealthCare, Education, infrastructure development, Community development, Women Empowerment, heritage protection, etc. Similarly (Harma and Kiran 2013) have done the assessment of the articles, and various kinds of literature from 1975 to 2011 to have an understanding of the theoretical and practical approach of CSR and its changes. It is found that change in the CSR activities as per the changing world and 


\begin{tabular}{l}
\hline GBR \\
Vol. 16 \\
111 \\
\hline
\end{tabular}

time. Researchers have focused on both implicit and explicit factors to do the holistic approach of CSR. The combination of Carroll's responsibilities plays a major role in the effective and efficient implementation of CSR. It has been found that organizations should not be strict on a single form of CSR practice even they should diversify themselves for diversified CSR practices as well as (Shyam 2016) has strengthen the concept of the study by providing the relevant information from the various sources of published data to develop the knowledge and understandings of the concept and development of CSR in India, to analyze the initiative and challenges of CSR in India. It is found that in India the concept of CSR is not new and it was initiated first by TATA's. CSR gains the importance of passing with time as it helps in getting various benefits.

\subsection{Concepts of CSR \& Sustainable Development (Quantitative Approach)}

However, with respect to quantitative analysis of the conception and scenario of CSR of different companies in India. (Sharma and Tomar 2013) has determined the areas in which the companies are contributing to CSR and its challenges. In its qualitatively analysis it has been done, it is found that companies are contributing to CSR through Upliftment of Society, Concern for Health \& Society, Child, and Women Welfare, Green Ecology, Development of Rural areas, Employee's Welfare, etc. It is observed that there should be a holistic approach of each Company towards CSR but the area of focus is limited, Companies hold also has to wider their approach to Development.

In India, the trend of CSR by investing more has been changed from "Charity to Responsibility". CSR in India is now treated to "Make a Difference" among other players in the market. And Government also made a provision to pay for the CSR, 2\% of Net Profit during a financial year. The initiatives in CSR changed to Sustainable initiatives from the responsive practices to make the improvement in the society and to make a change.

After that is has been found that few researchers were also studied and evaluated the effectiveness of CSR in India and studies the various secondary data like (Chaijed 2015) has studied the secondary data in defining Corporate Social Responsibility and evaluating the CSR in India. By analyzing very facts and figures, it is found that Australia has the highest spending per company at $\$ 123$ million in CSR, after that U.K is on second with $\$ 102$ million, followed by the U.S, after that Brazil with $\$ 55$ million. India's average CSR spend is $\$ 15$ million. In India, the most contribution is done for Education. As Chajjed determines $18 \%$ of the total expenditure of CSR is done on Education.

Similarly, (Mukhrjee, Bird, and Duppati 2018) have taken the sample for the study from Journal of Contemporary Accounting \& Economics of BSE listed Companies of the year 2008 to 2015 and also from the journals, reports, etc. to study the effectiveness of CSR and its impact on profitability and to study the expenditure sector of CSR. Quantitative analysis, regression coefficient, and Chow test are the tools that are used for the study. In this paper firstly the Companies are divided into 4 groups. Group A includes companies that we're spending on CSR, Group B includes the companies that were not spending in CSR, Group C included the companies that we're spending on CSR it was not mandatory for them to spend and Group D includes the companies that were not spending on CSR it was not mandatory for them to spend and after that quantitatively the average CSR spending, Profit, Quick Ratio, ROE, Age, Sales, Leverages were formulated and analyze of these four groups companies. Chow Test is also used to find the difference and it is found that there is a large difference in CSR spending pre to post legislation (Company Act 2013). Regression analysis was also used to find the difference in CSR spending of these 4 groups for the year (20082015). It is found that legislation has generated a certain level of CSR spending which fell below the expectations. This paper also found that relationship of profitability and CSR spending, smaller companies were mostly affected by CSR expenditure after the legislation as CSR expenditure not mandatory for them so they need to reduce this expenditure which may increase their profit. On the other hand another some researchers like (Kapoor and Dhamija 2017) have studied the 500 indexes of Stock Exchange S\& P BSE listed Companies to determine the study focus of these companies on CSR and for the content analysis to quantify the CSR spending of Indian Companies. By analyzing the data it is found that only 
374 companies are there out of 500 who are spending on CSR.As per ACE database out of 373,343 companies are from the private sector and 31 companies are from public sector. 199 companies are there who have spent more than their mandatory amount in the first year of implementation of the CSR projects. It is also found in the room the study that MNC companies are doing better by $77 \%$ of spending their mandatory amount, $75 \%$ by the private sector, and $74 \%$ by PSUs. $2 / 3$ rd of the sample companies are there who have spent more than $75 \%$ mandatory amount for the CSR activities. MNCs have performed better in spending the CSR amount other than the private sectors and PSUs whereby (Verma and Singh 2016) have studied 20 top companies from the BSE 500 index for the year $2010-2014$ to determine how much top companies are disclosing or reporting in CSR activities and how the size of a company and its profitability affect the CSRD. The data has been analyzed more precisely with the content analysis, Multiple Regression analysis, Mean, Standard Deviation. Out of selected 20 companies from BSE, 4 companies were from Oil and gas, 4 from power, from metal and mining, 4 from financial companies and 4 were from Banking, these companies contribute to CSR in different aspects like Environmental Activities, Community Development Activities, Human Resource Activities, Product, and services Activities. It is found from the study that companies are disclosing CSR approx. $60 \%$ and maximum contribution was done in the HR activities theme 100\%, 95\% in Community Development, $85 \%$ in Product and Services, 85\% in Environmental Activities. No significant relationship is found from the calculation between firm size, ROE and CSRD which indicates that ownership of the companies has an impact on CSRD and it is also found that public sector companies are doing more contribution in CSR as compared to that of Private sector Companies. From the multiple regression analysis, no significant relationship is found between company profitability and CSR disclosure which indicates that it is not also found that highly profitable companies are more engaged in CSR activities.

\subsection{Concept of CSR \& Sustainable Development (Business Ethics Approach)}

The effectiveness of CSR is based on the priorities of corporate. CSR is something beyond charity and donation and similarly supporting this study (Singh 2016) has also studied the secondary data to get the information related to the concept of CSR, issues, and challenges of CSR in India, to study the status of India in terms of CSR; from the study, it is found that there are some issues in CSR. The importance of CSR in India is in a way that ensures its active presence in CSR. Competitive context along with the development of quality of the business environment is done as the result of Corporate Philanthropy. He also finds the challenges of CSR which affect it a lot, the challenges are Lack of Community Participation in CSR Activities, Need to Build Local Capacities, on-availability of Well Organized NonGovernmental Organization, visibility factor, Lack of Consensus on Implementing CSR Issues. The status of CSR in India is at a growing status whereas (Kishor, and Sharma 2013) analyze the various secondary data to analyze the new innovative ideas in the implementation of CSR in India and to find the fundamental changes in CSR, analyze the change in the trend of CSR (from 1800 to till now). Initially, CSR was viewed as the philanthropy with religious belief, then in the form of donations for the welfare of the society, after that responsible behavior with a progressive approach and now it multi-dimensional with respect to social interest. Various innovations have been taken place; CSR changed his dimension from responsive activities to sustainable initiatives that help to make a significant position and image in the society with the development and improvement in the standard of living. As well as some researcher like (Poonam 2016) has investigated the various secondary data to find the factor that directly or indirectly impacts the CSR on Socioeconomic Development, and increase the understanding of the concept of CSR and to understand the initiatives taken by selected PSUs and private players. She used Carroll Model to study Social Responsibility; it was found by the study that the main leading companies are involved in CSR with the focus area on livelihood creation, development of skills, and uplift the people belongs to below poverty line and Education. Companies like TATA, Infosys, Indian Oil Corporation are the Company that makes noticeable efforts in CSR. It is found from the data interpretation that the PSUs are making a priority to Education, then Health followed by livelihood. 


\begin{tabular}{l}
\hline GBR \\
Vol. 16 \\
113 \\
\hline
\end{tabular}

2.4 Concept of CSR \& Sustainable Development (Innovative Approach)

The innovation made by the Companies in CSR is the Societal marketing concept of companies, it is the latest trend in CSR as found by the study whereas (Nadaf and Nadaf 2015) has studied the data from secondary resources to discuss the role of CSR, and to underline the issues and challenges that come in the implementation of CSR activities found that CSR is Sustainable with the activities that an organization can hold without causing any the negative impact of the business goal or society. CSR implementation includes some aspects i.e. Customers, Suppliers, Environment, Community, and Employees. They also define the challenges of CSR and its benefits to employees and Customers. CSR in India undergoes through various models, it also defines the various models of implementing CSR and later on by analyzing the secondary source of information and on the basis of an empirical application of CSR (Gupta and Arora 2013) has analyzed the spending on CSR in India by various Companies and to differentiate between Corporate Social Responsibility and Corporate Philanthropy. By understanding Corporate Philanthropy and CSR it is found that Corporate Philanthropy has a limited and narrow approach while CSR has a much wider approach. CSR is the one who considers the overall development of the Customer, Employee, Environment, local community. From the data of the ranking of Indian top Companies collected by CSRidentity.com, together with Forbes, it is found that among the top 100 firms by revenue, some companies don't report their CSR spends. Companies that put Social Responsibility before profit can survive in the competitive era. (Siddiqui 2014) has also tried to prove the CSR initiatives and its positive impact on business organization with the help of case study through the paper entitled CSR and Environmental Sustainability Initiatives: A Case Study of NMDC Ltd, studied the secondary data to bring into sight the various CSR initiatives are undertaken by NMDC Ltd., to bring into sight the various CSR initiatives are undertaken by NMDC Ltd. This paper analysis the provisions of Companies Act 2013 relating to the CSR and Sustainability guidelines, along with defining the schedule VII of Companies ACT which defines the activities under CSR. More than 194 children from remote villages have been brought into the school in classes I to III through the visit of NMDC volunteers. It is defined by the research Major initiatives CSR initiatives taken by NMDC Ltd. are Education, Scholarship schemes and mid-day meals, tube wells \& hand pump constructions for hygienic drinking water and also focused on the development of skills for self-dependency, Medical Healthcare and Rural Area Development, etc. whereas (Maheshwari and Kaura 2014) have studied 30 top companies out of 100 index S \& P BSE listed companies of two years (2011-13) to determine the environmental aspect of CSR Disclosure in India and to find out the relationship between environmental aspect and CSRD. 30 companies include 9 manufacturing, 8 power generation, 7 construction and 6 pharmaceuticals companies.

For these 30 randomly selected companies different environmental aspects analyzed in which companies were contributing. It is found that companies are contributing to the sectors like Air emission, solid waste disposal, water discharge, Research on finding new methods of production by reducing environmental pollution, installation of effluent treatment plant etc. and as per CSRD most disclosure the theme is air emission $96 \%$ and after that solid waste management with $90 \%$. and the theme which is least disclose was Research on finding new methods of production by reducing environmental pollution with $50 \%$.In Indian Companies only 260 out of 483 are disclosed and 72 statement are those only descriptive that is the least choice of Corporate.

\subsection{Research Gap}

From the above we can say that most of the studies are conducted to know for which CSR activities companies are spending the amount and which companies are disclosing or reporting their CSR activities. In the present study we have taken different indices i.e. S\&P BSE 100 Companies. Further, the study has compared the amount to be spent on CSR and the actual amount spent on CSR activities which are not considered in the other studies.

\section{Research Methodology}

Data Collection Procedure: The study is based on the secondary data which is collected 
from the Prowess IQ database.

Sample: The study considered the S\&P BSE 100 Companies.

Corporate Social

Responsibility and

Method: The data is analyzed through SPSS version 22. The t-test is used to determine whether there is any significant difference in the actual expenditure on CSR and the expenditure to be done as per the CSR provision of companies' act 2013. Descriptive statistics are used to know the average, maximum and minimum values of CSR.

\section{Analysis, Result and Discussion}

Relationship between the amount to be spent on CSR and the actual amount spent on CSR: To know whether there is any significant difference exists between the amount to be spent on CSR and the actual amount spent on CSR t-test has been performed. The null hypothesis for the same is:

H0: There is no significant difference exists between the amount to be spent on CSR and the actual amount spent on CSR.

\begin{tabular}{|c|c|c|}
\hline YEAR & T-Value & P-Value \\
\hline 2014 & -0.772 & 0.441 \\
\hline 2015 & -0.564 & 0.573 \\
\hline 2016 & -0.37 & 0.771 \\
\hline 2017 & -0.302 & 0.763 \\
\hline 2018 & -0.31 & 0.757 \\
\hline
\end{tabular}

Table 1.

t-Test between amount to be spent and actual amount spent on CSR

From the above table, we can see that the p values during the years 2014 to 2018 are more than .05 , hence we fail to reject the null hypothesis. Thus, we can conclude that there is no significant difference exists between the amount to be spent on CSR and the actual amount spent on CSR. All the t-values are negative which implies that the mean score of actual spending on CSR is less as compared to the mean score of the amount to be spent on CSR. It implies that the actual spending on CSR is less.

\section{CSR-Unspent Amount:}

\begin{tabular}{|c|c|c|c|c|c|}
\hline & $\mathbf{2 0 1 4}$ & $\mathbf{2 0 1 5}$ & $\mathbf{2 0 1 6}$ & $\mathbf{2 0 1 7}$ & $\mathbf{2 0 1 8}$ \\
\hline Sum & 14005.18 & 12819 & 11535 & 9949.19 & 9652.5 \\
\hline Average & 168.737 & 145.07 & 124.032 & 108.143 & 106.068 \\
\hline Maximum & 1653.8 & 1727 & 2126.7 & 1900.9 & 1900.9 \\
\hline Minimum & 0 & 0 & 0 & 0 & 0 \\
Table 2.
\end{tabular}

From the above table-2, we can analyze that from the year 2014 to the year 2018 the unspent amount of CSR is reducing continuously (i.e. from 14005.18 million to 9652.2 million). Which shows that the organizations are spending more and more on CSR activities. The average unspent amount is also reduced to 106 million from 169 million (approx).

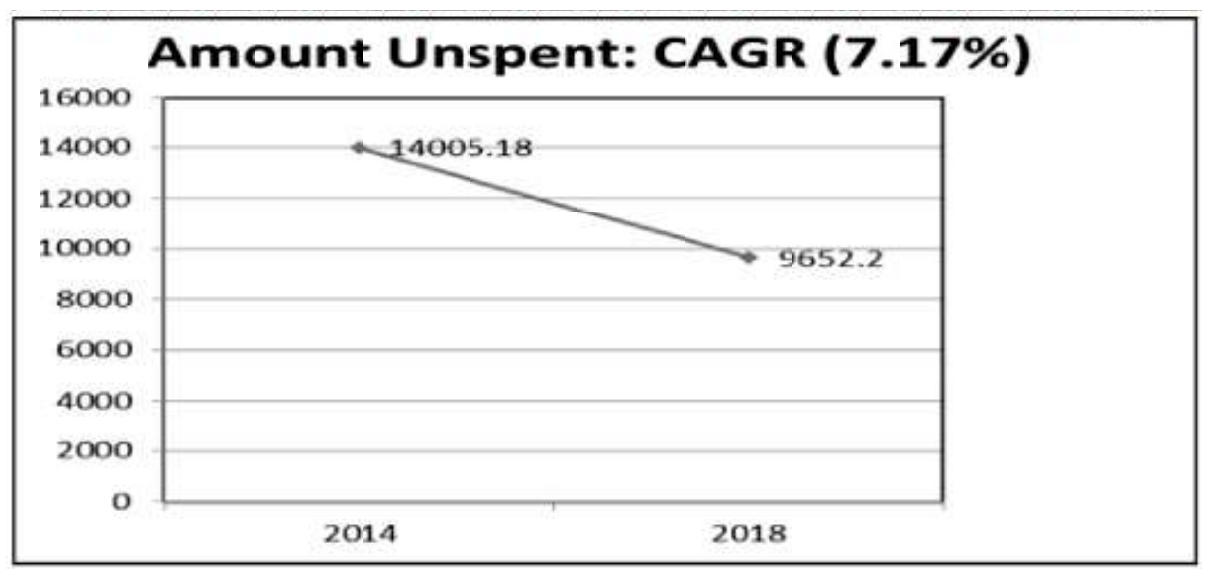

Figure 2.

CAGR-Unspent Amount 


\begin{tabular}{ll}
\hline GBR & From the above Figure, we can analyze that the CAGR value is negative (i.e. 7.55\%) which \\
Vol. 16 & indicates that the unspent amount is decreased from 2014 to 2018. This is a good indication \\
& for India that the firms are spending more on CSR activities.
\end{tabular}

115

CSR - Amount to be Spent as per the Companies Act, 2013

\begin{tabular}{|c|c|c|c|c|c|}
\hline & $\mathbf{2 0 1 4}$ & $\mathbf{2 0 1 5}$ & $\mathbf{2 0 1 6}$ & $\mathbf{2 0 1 7}$ & $\mathbf{2 0 1 8}$ \\
\hline Sum & 58307.18 & 65599.6 & 70891.94 & 76170.2 & 76706.2 \\
\hline Average & 694.133 & 737.074 & 760.128 & 810.321 & 816.03 \\
\hline Maximum & 6606.1 & 5937 & 6204.1 & 7030.8 & 7030.8 \\
\hline Minimum & 13.9 & 16 & 15.9 & 18.3 & 18.3 \\
\hline
\end{tabular}

From the above Table-3, we can analyze that from the year 2014 to the year 2018 the amount to be spent on CSR activities is increased from 58307 million to 76707 million. It is as per the provision of companies act on CSR

Figure 3.

CAGR-Amount to be spent on CSR

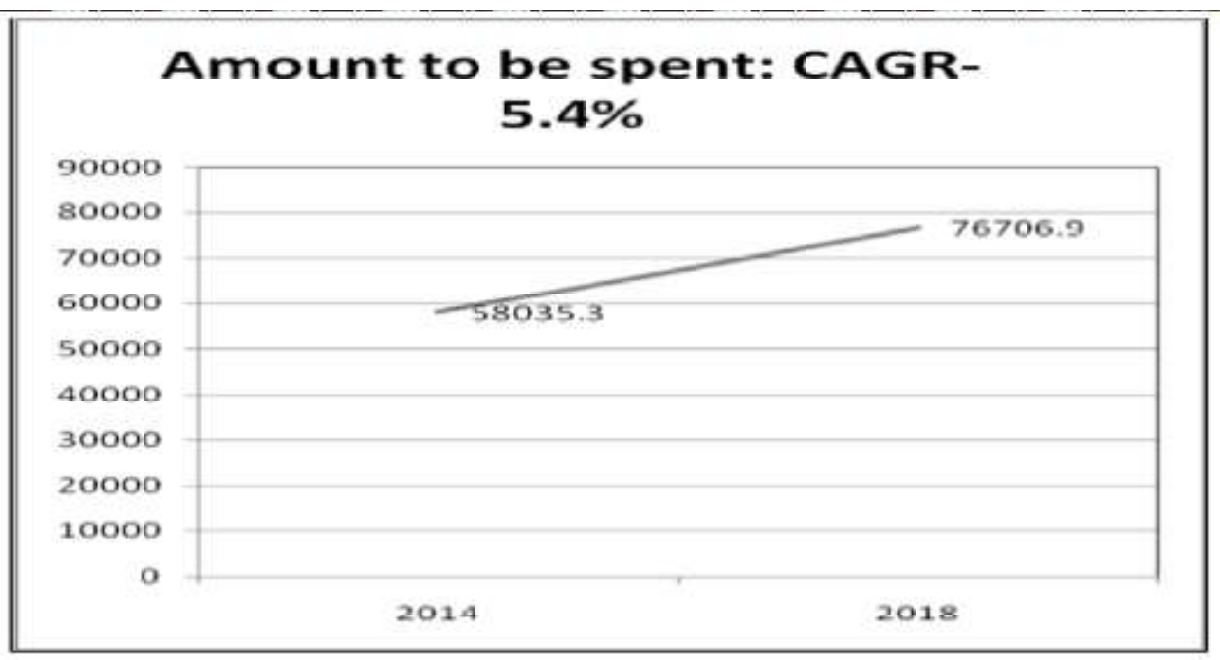

From the above figure, we can analyze that the CAGR value of the amount to be spent on CSR is $5.4 \%$. It shows that the profits are increasing so the amount to be spent on CSR is also increasing.

\section{Actual CSR Amount Spent:}

Table 4.

Actual Amount spent on CSR

\begin{tabular}{|c|c|c|c|c|c|}
\hline & $\mathbf{2 0 1 4}$ & $\mathbf{2 0 1 5}$ & $\mathbf{2 0 1 6}$ & $\mathbf{2 0 1 7}$ & $\mathbf{2 0 1 8}$ \\
\hline Sum & 50445.6 & 59893.4 & 66762.6 & 72844.8 & 73224.3 \\
\hline Average & 554.377 & 630.4563 & 681.251 & 758.8 & 762.753 \\
\hline Maximum & 7605.8 & 6515.7 & 6592 & 7450.4 & 7450.4 \\
\hline Minimum & 0 & 0 & 0 & 8.5 & 8.5 \\
\hline
\end{tabular}

From the above Table-4, we can analyze that from the year 2014 to the year 2018 the actual amount spent on CSR is increasing continuously (i.e. from 50445.6 million to 73224.3 million). This shows that the organization's spending on CSR is increasing year after year. The above finding is similar to the finding of Singh (2016). The average amount spent is increased to 763 million from 554 million (approx). 


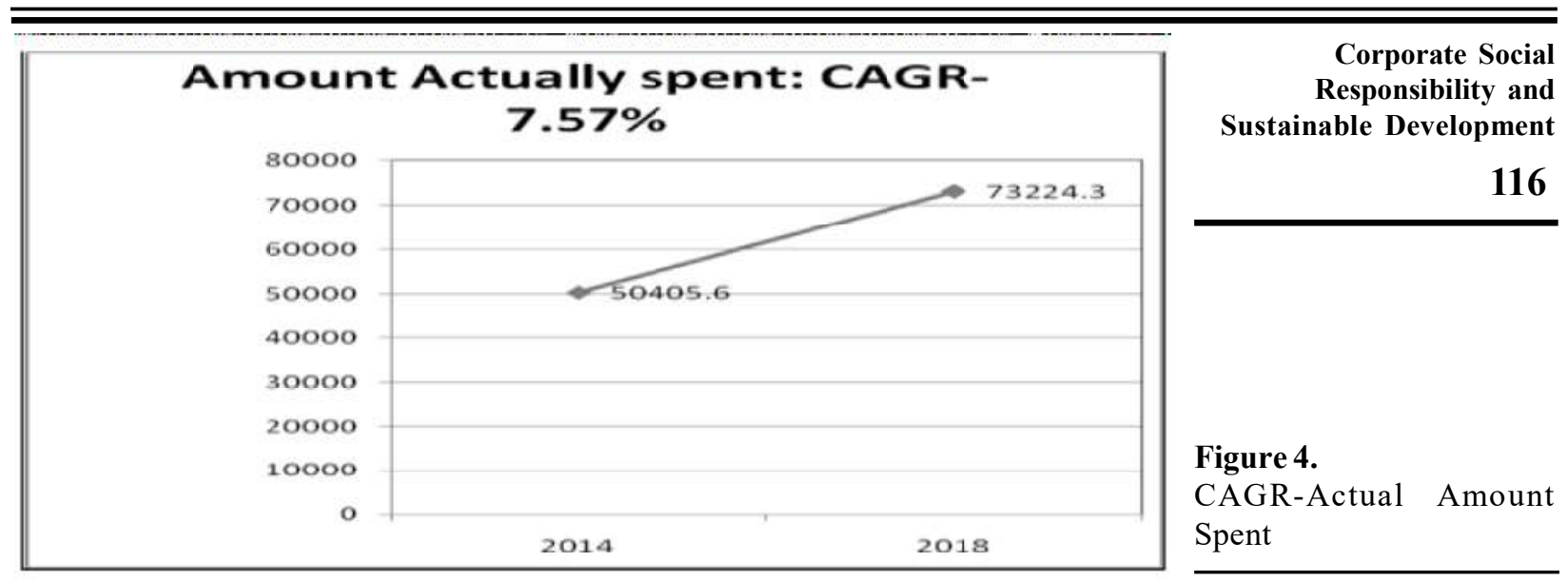

From the above Figure, we can analyze that the CAGR value is $7.57 \%$. This indicates that the amount spent is increased from 2014 to 2018. This is a good indication for India that the firms are spending more on CSR activities.

\section{Over / Under expenditure on CSR:}

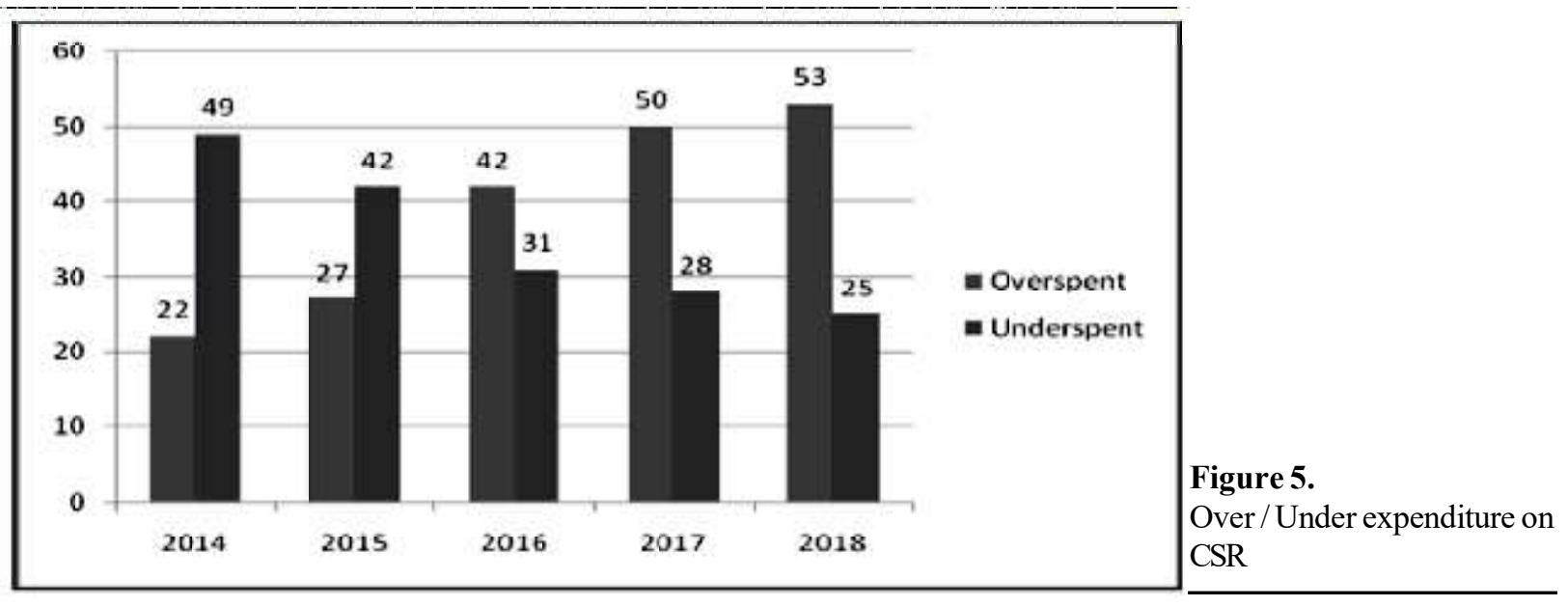

From the above Figure, we can analyze that the overspent amount is increasing continuously. From 22 firms in 2014 which are overspending on CSR activity as per the provision in 2018 total of 53 firms spent more amounts on CSR. On the other hand, under spending firms decreased to 25 firms in 2018 from 49 firms from 2014.

\section{Conclusion}

From the above, we can conclude that the S\&P BSE 100 Companies are moving in the direction of spending more and more amount on CSR activities such as health care, education, rural development, gender equality, and slum area development, etc., mostly the elements which are used as a tool for sustainable development. The CAGR value of the spending amount on CSR is also positive and showing a growth of approx 8\% during the year 2014 to 2018. This is a positive sign for India for sustainable development. On the other hand, the unspent amount is showing a negative CAGR which shows that there is a decrease in the unspent amount on CSR which is again a good sign for a country. The study also concludes that there is no significant difference in the amount to be spent on CSR as per the provision and the actual amount spent on CSR. This shows that most of the firms are following the provision of Company Act, 2013 on CSR. More than $50 \%$ of the companies have spent more amount as per the legal requirement in 2018; which indicates that the companies are not 
doing CSR activity as a legal obligation but they are doing it willingly which will lead to sustainable development.

\section{Managerial \& Practical Implications}

The first step for the for sustainable development and environmental protection, top management, policymaker and critical decision-maker in any organizations should participate in social, health care, education, rural development, gender equality and environmental activities, and establishing the appropriate accountability mechanisms towards moving in the the direction of spending more and more amount on CSR activities \& communicate it to the members of the organization and stakeholders.

To avoid the legal obligation as well as to lead to sustainable development. Apart from this corporate houses should seek cost-effective and efficient ways of reducing the expenses and other resources associated with day-to-day operations for the sustainable development.

\section{Limitations and Scope for Further Studies}

The study is based on the secondary data taken from the Prowess IQ database. Study has covered only S\&P BSE 100 Companies. Further, studies can be conducted with other indices to know their amount of spending on CSR and following the provision of Company Act, 2013 on CSR.

\section{References}

Begum, Y. R. and Nadaf, S. M. (2015), "Corporate Social Responsibility: Issues Challenges and Strategies for Indian Firms”, IOSR Journal of Business and Management, Vol.16 No. 5, pp. 51-56.

Behringer, K. and Szegedi, K., (2016), "The role of CSR in achieving sustainable developmenttheoretical approach", European Scientific Journal, Vol. 12 No. 22, pp. 10-25.

Bhagwat, P. (2011), "Corporate Social Responsibility and Sustainable Development", in Conference on Inclusive \& Sustainable Growth, IMT Ghaziabad.

Chhajed, V. K. (2015), "Corporate Social Responsibility: Current Scenario", International Journal of Management Research \& Review, Vol. 5 No. 3, pp. 211-214.

Dodh, P., Singh, S. and Ravita (2013), “Corporate Social Responsibility and Sustainable Development in India", Global Journal of Management and Business Studies, Vol. 3 No. 6, pp. 681-688.

Gupta, S. K. and Arora, A. K., (2013), "Corporate social responsibility: A business imperative", The Management Accountant Journal, Vol. 48 No. 6, pp. 660-666.

Kapoor, G. K. and Dhamija, S. (2017), "Mandatory CSR spending-Indian experience" Emerging Economy Studies, Vol. 3 No. 1, pp. 98-112.

Kumar, R., (2019), "CSR in Indian Organization: A Conceptual Framework”, International Journal of Business and Management Invention, Vol. 8 No. 3, pp. 44-46.

Maheshwari, M. and Kaura, P. (2014), "Corporate social reporting and disclosure practice in India: An empirical investigation”, International Journal of Research, Vol. 1 No. 8, pp. 1099-1109.

Mukherjee, A., Bird, R. and Duppati, G. (2018), "Mandatory corporate social responsibility: The Indian experience", Journal of Contemporary Accounting \& Economics, Vol. 14 No. 3, pp. 254-265.

Nayaka, K. M. D., Usman, M. (2015), “A review of Corporate Social Responsibility (CSR) and inclusive growth in India", Journal of Management Research, Vol. 4 No.1, pp. 38-42.

Poonam (2016), "Corporate Social Responsibility in Rural Development Sector: An Introduction", International Journal of Advance Research and Innovative Ideas in Education, Vol.2 No.1, pp.884-889.

Sharma, A. and Kiran, R. (2013), "Corporate Social Responsibility: Driving Forces and Challenges", International Journal of Business Research and Development, Vol. 2 No.1, pp. 18-27.

Sharma, S. K., and Tomar, A. (2013), "Corporate Social Responsibility and Sustainable Development", Journal of Indian Research, Vol.1 No.4, pp.112-114

Sharma, S., Sharma, R. and Kishor, J. (2013), "Emerging Trends in Corporate Social Responsibility in India", Global Journal of Commerce \& Management Perspective, Vol. 2 No.2, pp. 58-62.

Shyam, R., (2016), "An Analysis of Corporate Social Responsibility in India", International Journal of Research - Granthaalayah, Vol. 4 No.5, pp. 56-64. 
Siddiqui, S. J. (2014), "CSR and Environmental Sustainability Initiatives: A Case Study of NMDC Ltd", International Journal of Business and Administration Research Review, Vol.1 No.7, pp.116-126.

Corporate Social

Responsibility and

ingh, C. (2016), "CSR: Issues and Challenges in India", International Journal of Advance Research and Innovative Ideas in Education, Vol. 2 No.6, pp.1674-1679.

Sustainable Development

P. and Singh, A (2016) "Fostering stakeholders trust through CSR reporting: An analytical focus", IIM Kozhikode Society \& Management Review, Vol.5 No.2, pp. 186-199.

\section{Annexure: List of S \& P BSE 100 Companies}

\begin{tabular}{|c|l|}
\hline $\begin{array}{c}\text { S. } \\
\text { No. }\end{array}$ & \\
\hline 1 & A C C Lt d. \\
\hline 2 & Adani Ports \& Special Economic Zone Ltd. \\
\hline 3 & Ambuja Cements Ltd. \\
\hline 4 & Apollo Hospitals Enterprise Ltd. \\
\hline 5 & Ashok Leyland Ltd. \\
\hline 6 & Asian Paints Ltd. \\
\hline 7 & Aurobindo Pharma Ltd. \\
\hline 8 & Axis Bank Ltd. \\
\hline 9 & Bajaj Auto Ltd. \\
\hline 10 & Bajaj Finance Ltd. \\
\hline 11 & Bajaj Finserv Ltd. \\
\hline 12 & Bajaj Holdings \& Invst. Ltd. \\
\hline 13 & Bharat Electronics Ltd. \\
\hline 14 & Bharat Forge Ltd. \\
\hline 15 & Bharat Heavy Electricals Ltd. \\
\hline 16 & Bharat Petroleum Corpn. Ltd. \\
\hline 17 & Bharti Airtel Ltd. \\
\hline 18 & Bharti Infratel Ltd. \\
\hline 19 & Biocon Ltd. \\
\hline 20 & Bosch Ltd. \\
\hline 21 & Britannia Industries Ltd. \\
\hline 22 & Cadila Healthcare Ltd. \\
\hline 23 & Cipla Ltd. \\
\hline 24 & Coal India Ltd. \\
\hline 25 & Colgate-Palmolive (India) Ltd. \\
\hline 26 & Container Corpn. Of India Ltd. \\
\hline 27 & Crompton Greaves Consumer Electricals Ltd. \\
\hline 28 & Cummins India Ltd. \\
\hline 29 & D L F Ltd. \\
\hline 30 & Dabur India Ltd. \\
\hline 31 & Divi'S Laboratories Ltd. \\
\hline 32 & Dr. Reddy'S Laboratories Ltd. \\
\hline 33 & Edelweiss Financial Services Ltd. \\
\hline 34 & Eicher Motors Ltd. \\
\hline 35 & Exide Industries Ltd. \\
\hline 36 & Federal Bank Ltd. \\
\hline 37 & G A I L (India) Ltd. \\
\hline 38 & Glenmark Pharmaceuticals Ltd. \\
\hline 39 & Godrej Consumer Products Ltd. \\
\hline 40 & Grasim Industries Ltd. \\
\hline 42 & H C L Technologies Ltd. \\
\hline & H D F C Bank Ltd. \\
\hline 43 & Havells India Ltd. \\
\hline
\end{tabular}


GBR

Vol. 16

119

\begin{tabular}{|c|c|}
\hline 44 & Hero Motocorp Ltd. \\
\hline 45 & Hindalco Industries Ltd. \\
\hline 46 & Hindustan Petroleum Corpn. Ltd. \\
\hline 47 & Hindustan Unilever Ltd. \\
\hline 48 & Housing Development Finance Corpn. Ltd. \\
\hline 49 & I C I C I Bank Ltd. \\
\hline 50 & ICICI Prudential Life Insurance Company Ltd. \\
\hline 51 & I T C Ltd. \\
\hline 52 & Indiabulls Housing Finance Ltd. \\
\hline 53 & Indian Oil Corpn. Ltd. \\
\hline 54 & Indusind Bank Ltd. \\
\hline 55 & Infosys Ltd. \\
\hline 56 & J S W Steel Ltd. \\
\hline 57 & Kotak Mahindra Bank Ltd. \\
\hline 58 & L I C Housing Finance Ltd. \\
\hline 59 & Larsen \& Toubro Ltd. \\
\hline 60 & Lupin Ltd. \\
\hline 61 & M R F Ltd. \\
\hline 62 & Mahindra \& Mahindra Financial Services Ltd. \\
\hline 63 & Mahindra \& Mahindra Ltd. \\
\hline 64 & Marico Ltd. \\
\hline 65 & Maruti Suzuki India Ltd. \\
\hline 66 & Motherson Sumi Systems Ltd. \\
\hline 67 & N M D C Ltd. \\
\hline 68 & N T P C Ltd. \\
\hline 69 & Nestle India Ltd. \\
\hline 70 & Oil \& Natural Gas Corpn. Ltd. \\
\hline 71 & Page Industries Ltd. \\
\hline 72 & Petronet L N G Ltd. \\
\hline 73 & Pidilite Industries Ltd. \\
\hline 74 & Piramal Enterprises Ltd. \\
\hline 75 & Power Grid Corpn. Of India Ltd. \\
\hline 76 & Punjab National Bank \\
\hline 77 & R E C Ltd. \\
\hline 78 & RBL Bank Ltd. \\
\hline 79 & Reliance Industries Ltd. \\
\hline 80 & Shree Cement Ltd. \\
\hline 81 & Shriram Transport Finance Co. Ltd. \\
\hline 82 & Siemens Ltd. \\
\hline 83 & State Bank Of India \\
\hline 84 & Sun Pharmaceutical Inds. Ltd. \\
\hline 85 & T V S Motor Co. Ltd. \\
\hline 86 & Tata Chemicals Ltd. \\
\hline
\end{tabular}




\begin{tabular}{|c|l|}
\hline \hline & \multicolumn{2}{|c|}{} \\
\hline 87 & Tata Consultancy Services Ltd. \\
\hline 88 & Tata Global Beverages Ltd. \\
\hline 89 & Tata Motors Ltd. \\
\hline 90 & Tata Power Co. Ltd. \\
\hline 91 & Tata Steel Ltd. \\
\hline 92 & Tech Mahindra Ltd. \\
\hline 93 & Titan Company Ltd. \\
\hline 94 & U P L Ltd. \\
\hline 95 & Ultratech Cement Ltd. \\
\hline 96 & Vedanta Ltd. \\
\hline 97 & Vodafone Idea Ltd. \\
\hline 98 & Wipro Ltd. \\
\hline 99 & Yes Bank Ltd. \\
\hline 100 & Zee Entertainment Enterprises Ltd. \\
\hline
\end{tabular}

Corporate Social

Responsibility and

Sustainable Development 